\title{
Modelación numérica con validación experimental aplicada al estudio del comportamiento de conectores tipo perno de estructuras compuestas de hormigón y acero Numerical modelling with experimental validation applied to the study of stud connectors behaviour in concrete and steel composite structures
}

\author{
Jorge Bonilla ${ }^{1} *$, Luciano M. Bezerra**, Rafael Larrúa***, Carlos Recarey****, Enrique Mirambell*****
}

* Universidad de Ciego de Ávila. CUBA

** Universidad de Brasilia (UnB), DF. BRASIL

*** Universidad de Camagüey (UC), Camagüey. CUBA

**** Universidad Central de Las Villas (UCLV). CUBA

***** Universidad Politécnica de Cataluña (UPC), Barcelona. ESPAÑA

Fecha de Recepción: 19/06/2014

Fecha de Aceptación: 30/11/2015

PAG 53-68

\begin{abstract}
Resumen
En este trabajo se realiza un estudio del comportamiento de conectores tipo perno de estructuras compuestas de hormigón y acero mediante la simulación numérica del ensayo push out en sección viga-losa maciza de hormigón. Se analiza el comportamiento de los materiales en régimen no lineal, empleándose en un primer caso un modelo bilineal con criterio de rotura de Von Mises para el acero y el hormigón, y en un segundo caso un Modelo de Daño Plástico para el hormigón. Como herramienta para la modelación numérica se emplea el programa computacional ABAQUS. Se aborda el procedimiento metodológico de modelación numérica del ensayo de conectores. Se observa una buena correspondencia existente entre los resultados numéricos y experimentales, evidenciándose la efectividad del uso del Método de Elementos Finitos para el estudio del comportamiento de conectores. Finalmente, respaldado por los estudios numéricos y experimentales, se realiza una valoración de precisión en la estimación de la capacidad resistente de los conectores obtenida a partir de las normativas: AISC-LRFD (2005), Eurocódigo 4 (2004) y
\end{abstract} la Normativa Ramal Cubana NR-080-2004, observando que dichas normativas sobreestiman este valor en muchos casos.

Palabras claves: Estructuras compuestas, conectores perno, simulación numérica, método de elementos finitos, modelo de daño plástico.

\begin{abstract}
In this work, the behaviour of stud shear connectors in composite structures is studied, starting from the via numeric simulation of the push out test in a steel beam with solid concrete slab concrete section is studied. The study considers material non-linearity material of concrete and steel, adopting firstly a bilinear model for both (steel and concrete), and in the second case, to the difference ofdiffering from other authors, the concrete damage plasticity of the concrete. ABAQUS is used to model the push out test. The basis and methodology of the modelmodelling process push out test are explained. The numerical results obtained are in accordance with the experimental results, which. This aspect shows the efficacythat of the finite element method is efficient for the in studying the behaviour of stud shear connector's behavior. Finally, the capacities of shear connections obtained from the finite element analysis were are compared with to the connection strengths calculated using the American Specification (AISC-LRFD (2005)), European Code (Eurocode 4 (2004)) and Cuban Code (NR-080-2004). ItThis was is observed that, these specifications over estimate this value (capacities of shear connections) in many cases.
\end{abstract}

Keywords: Composite structures, stud shear connectors, numerical simulation, finite element method, concrete damaged plasticity

\section{Introduction}

Composite structures combine two materials in a structural unit, making efficient use of the properties of each material. Composites made of concrete and flexible steel are mainly used in mezzanines. This paper studies the type formed by steel beams connected to slabs of concrete using connectors, where the latter allow for joint structural work between the slab and metal profile.

According to Rambo-Roddenberry (2002), due to the complexity of the tensional states at the connection, the experimental method is used - the push out test being the standard - to study the behaviour of connectors since it first appeared around the year 1920.

\footnotetext{
1 Autor de correspondencia / Corresponding author:

Doctor en Ciencias Técnicas. Profesor de Estructuras e Investigador en el campo de los métodos numéricos aplicados a la ingeniería. Director del Grupo de Investigaciones de Métodos Numéricos en la Ingeniería de la Universidad de Ciego de Ávila. Miembro del Consejo Científico de la Universidad de Ciego de Ávila. Cuba

E-mail: jorgedbr@informatica.unica.cu
} 
In this paper, the study of connector behaviour is carried out combining numeric simulation and experimentation as a means for calibration and validation. To complete this task, the push out test in a beam-concrete slab section was virtually modelled. The study employed ABAQUS, a computer program based on the Finite Element Method (FEM), as a numerical tool.

To model the behaviour of the materials, a bilinear model with Von Mises yield criterion was first proposed for steel (profile and studs) and concrete. Later, a Concrete Damage Plasticity Model was used, differing from the research by Lam and Ellobody (2005), and Ellobody and Young (2006).

The methodology to deal with the modelling and numeric simulation of the push out test is proposed using mathematic calibration. Finally, the good correspondence achieved between simulation and experimentation is corroborated. Results derived from the simulation with prior calibration are compared to the resistant capacity values theoretically estimated using the norms AISC-LRFD (2005), Eurocode 4 (EN-1994-1-1:2004) (EC-4) and the Cuban Norm $N R$ 080-2004. In various cases, an overestimation of the bearing capacity of said norms for different diameters of connectors and resistances of concrete were observed.

\section{Description of the specimen}

The experimental study by Lam and Ellobody (2005) was chosen as a means to the study of the connection's behaviour. The specimen studied for calibration (SP-2) (Figure 1) is composed of a segment with profile measurements of $W 10 \times 49$, and two rectangular concrete slabs built on each side of the profile in contact with the wings. The connection between the profile and the slabs is achieved using $19.05 \times 100 \mathrm{~mm}$ welded studs, with a yield tension of $470.8 \mathrm{MPa}$ and a modulus of deformation of $200000 \mathrm{MPa}$. The concrete slabs have a compressive strength of $20 \mathrm{MPa}$.

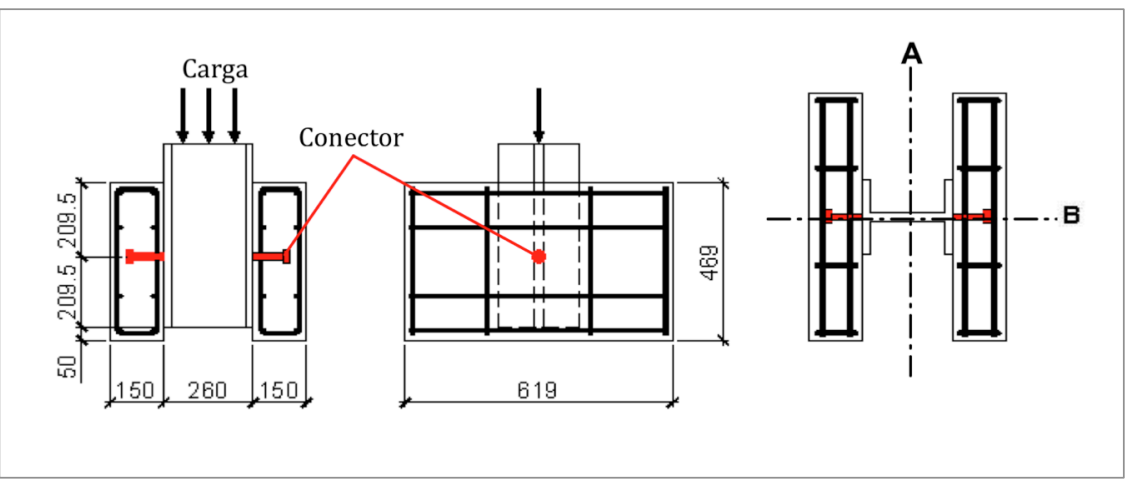

Figura 1. Probeta ensayada por Lam y Ellobody (2005)

Figure 1. Specimen used by Lam and Ellobody (2005) 


\section{Material modelling}

\section{a) Steel modelling}

Based on the work by Nie and Cai (2004), Lam and Ellobody (2005), Ellobody and Young (2006), and Hernandez et al. (2014) for the modelling of concrete-steel mixed structures, bilinear behaviour has been adopted in this study, with Von Mises yield criterion and an isotropic hardening yield surface.

\section{b) Concrete modelling}

For the modelling of concrete, a bilinear model with Von Mises yield criterion was first proposed based on the work by Lam and Ellobody (2005). Subsequently, the Concrete Damage Plasticity model available en ABAQUS was utilized, which is based on the models proposed by Lubliner et al. (1989), and Lee and Fenves (1998). This model is aimed at the analysis of concrete structures subject to monotonic, cyclic or dynamic stress. It simulates in a realistic fashion the irreversible damage associated to failure modes inherent to concrete and other geomaterials. The work by Hernandez et al. (2014) is a recent example of the aforementioned constitutive model's usage.

\section{Modelling of support, boundary or border conditions}

a) Studs have two interaction surfaces: the one associated to the stud-profile joint, and the stud-concrete interface. The stud-profile joint is treated as a rigid joint, because in the real life specimen it is achieved through a solder thread across the perimeter of the stud's base. To avoid numerical convergence issues the stud-concrete interface was modelled as rigid. Although it is known that there is no total continuity between the two materials, there is significant friction in some parts of the stud's surface due to the high levels of normal stress that are generated, especially in the vicinity of the connector's base. Moreover, electrochemical bonds exist at the interface. In their studies, Lam and Ellobody (2005), and Ellobody and Young (2006) use a rigid contact at the stud-concrete interface, disconnecting those nodes that have been experimentally proven not to participate in the contact.

In Model II, and for the sake of symmetry, only one fourth of the specimen is considered. In concordance with the element's continuity, in Figure 2 for surface 2, displacement along the $X$ axis is restricted.

b) Concrete slab: This element interacts with both stud and profile, and also with the support of the test press' base. Friction generated at the slab-profile interface is not taken into consideration, in accordance with EC-4 procedures for connector tests, wherein a film of grease is applied on the external side of the profile's wing. In this case, only normal contact has been generated between the two bodies. 
Model I: the slab's support is achieved on its lower part, designated as surface 1 , wherein displacement along the $Z$ axis is restricted and displacement along the $X$ and $Y$ axes is free (Figure 2).

Model II: As in Model I, displacement along the $Z$ axis is restricted and displacement along the $X$ and $Y$ axes is free. For surface 2, displacement along the $X$ axis is restricted (Figure 2).

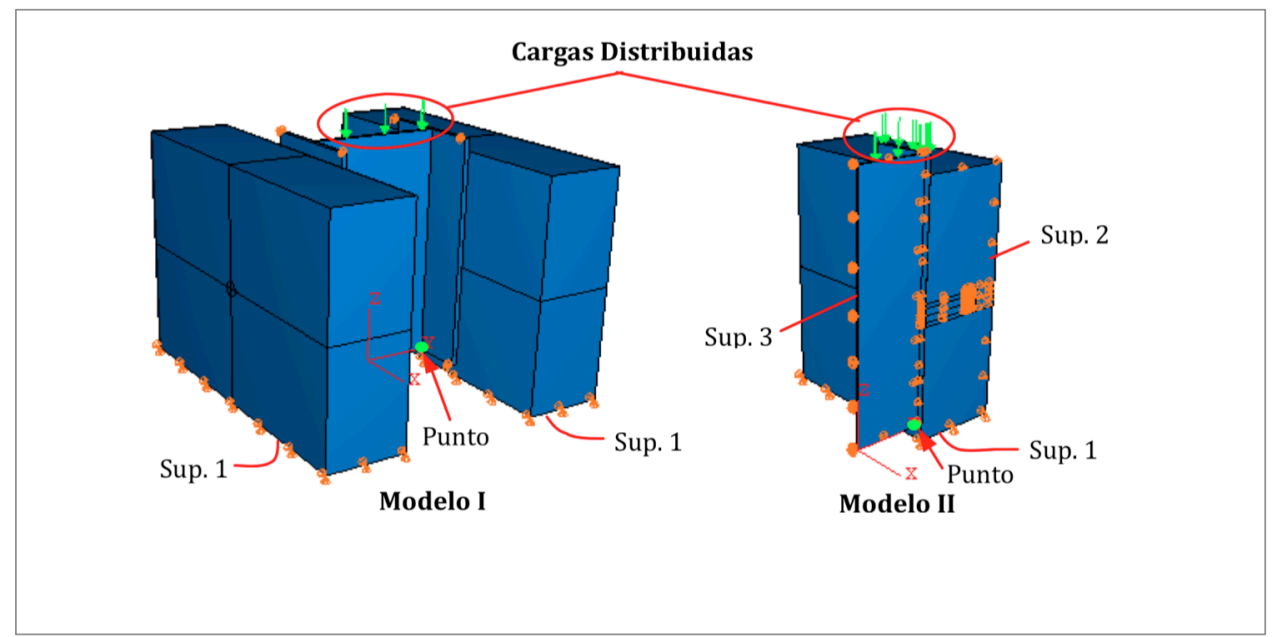

Figura 2. Vista en isométrico de la geometría de las probetas virtuales de los modelos I y II Figure 2. Isometric view of the geometry of Model I and II's virtual specimens

c) Profile I: is connected to the studs via a rigid interface, as described in (a). Load is applied in a distributed manner on the web and flange of the profile, as in the real life experiment. The load is increased in small intervals, the size of which is automatically selected by ABAQUS as a function of numerical convergence, using the RIKS algorithm. The algorithm is based on Newton's method and is generally used for the calculation of non-linearities and the prediction of structure collapse.

For surface 2 in Model II, displacement along the $X$ axis is restricted. Conversely, for surface 3 displacement along the $Y$ axis is restricted (Figure 2).

\section{Study and selection of the finite element to employ}

A study was carried out in order to select the optimal element type, one capable of most realistically reproducing the physical behaviour of the structure (push out test). To accomplish this, the volumetric geometry of each of the bodies that intervene in the model was discretised with C3D8R, C3D6 and C3D4 elements. Table 1 comparatively shows the results for different element configurations. Configuration $(D)$ gives the best approximation with relation to the experimental value, with an error or $1.64 \%$. C3D6 Lagrangian elements are used for the stud and surrounding concrete. For the meshing of the concrete slab, 
in areas far from the stud's vicinity, C3D4 elements are employed as they provide a better approximation compared to the rest. For the $W$ profile'smesh, C3D8R Langrangian elements are used, in accordance with the work of Lam and Ellobody (2005).

Tabla 1. Resultados de la simulación virtual con diferentes tipos de elementos

Table 1. Results of virtual simulation with different types of elements

\begin{tabular}{|c|c|c|c|c|c|}
\hline $\begin{array}{l}\text { Configuración/ } \\
\text { Configuración }\end{array}$ & Volumen/ Volume & Elemento/ Element & $\begin{array}{l}\text { Carga }(\mathrm{kN}) \\
\text { Load }(\mathrm{kN})\end{array}$ & $\begin{array}{l}\text { Desplaz. }(\mathrm{m}) \\
\text { Displac. }(\mathrm{m})\end{array}$ & Dif. $(\%)$ \\
\hline \multirow[t]{3}{*}{ A } & Losa/ Slab & C3D8R & \multirow[t]{3}{*}{119.61} & \multirow[t]{3}{*}{0.0038} & \multirow[t]{3}{*}{16.47} \\
\hline & Vecindad del conector/ Vicinity of connector & C3D8R & & & \\
\hline & Conector/ Connector & C3D8R & & & \\
\hline \multirow[t]{3}{*}{ B } & Losa/ Slab & C3D4 & \multirow[t]{3}{*}{162.42} & \multirow[t]{3}{*}{0.0038} & \multirow[t]{3}{*}{13.42} \\
\hline & Vecindad del conector/ Vicinity of connector & C3D4 & & & \\
\hline & Conector/ Connector & C3D4 & & & \\
\hline \multirow[t]{3}{*}{ C } & Losa/ Slab & C3D6 & \multirow[t]{3}{*}{138.87} & \multirow[t]{3}{*}{0.0038} & \multirow[t]{3}{*}{3.02} \\
\hline & Vecindad del conector/ Vicinity of connector & C3D6 & & & \\
\hline & Conector/ Connector & C3D6 & & & \\
\hline \multirow[t]{3}{*}{$\mathrm{D}$} & Losa/ Slab & C3D4 & \multirow[t]{3}{*}{145.55} & \multirow[t]{3}{*}{0.0038} & \multirow[t]{3}{*}{1.64} \\
\hline & Vecindad del conector/ Vicinity of connector & C3D6 & & & \\
\hline & Conector/ Connector & C3D6 & & & \\
\hline \multicolumn{3}{|c|}{ Experimental (SP-2 Lam y Ellobody (2005))/ Experimental (SP-2 Lam and Ellobody (2005)) } & 143.20 & 0.0038 & 0.00 \\
\hline \multicolumn{6}{|c|}{$\begin{array}{l}\text { Nota: La vecindad del conector es una partición en forma de anillo perimetral de hormigón de } 5.5 \mathrm{~mm} \text { de espesor que circunda a } \\
\text { vástago en toda su longitud. } \\
\text { Note: The vicinity of the connector is a } 5.5 \mathrm{~mm} \text { thick concrete perimetral ring partition that surrounds the entire length of the beam. }\end{array}$} \\
\hline
\end{tabular}

\section{Mesh density callibration}

After selecting the optimal element configuration, the mesh density is calibrated for adequate precision and optimal computational cost.

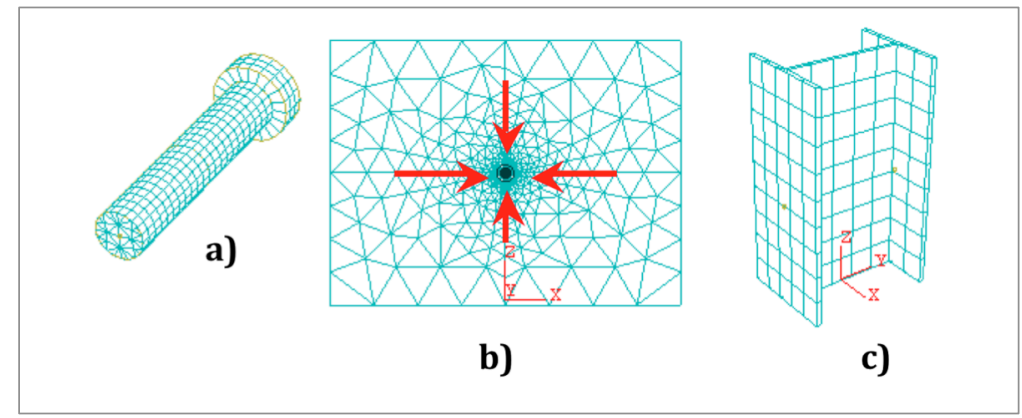

Figura 3. Vista en isométrico de la geometría de las probetas virtuales de los modelos I y II Figure 3. Discrete diagram. a) stud, b) frontal view of slab, c) profile 
Five different mesh densities are analysed for the studs and the concrete slabs, while maintaining a constant mesh for profile I as it has practically no influence, in this case, in the behaviour of the connection [Lam y Ellobody (2005)]. Figure 3 shows the discretisation of each of the elements that make up Model I. In the slab, represented in diagram (b), the arrows indicate the progressive increase in mesh density towards the vicinity of the connector, the zone with the highest concentration of stress. Five different densities have been studied in the connector with uniform distribution across the whole volume.

Table 2 shows the mesh configurations for Model 1, and the computational time (approximate) used in each solution. It is worth mentioning that computational costs are relative as they depend of the technology used, fundamentally the hardware.

Tabla 2. Configuración del modelo para diferentes densidades de malla

Table 2. Model configuration for different mesh densities

\begin{tabular}{|c|c|c|c|c|}
\hline Modelo/ Model & $\begin{array}{c}\text { Volumen/ } \\
\text { Volume }\end{array}$ & $\begin{array}{c}\text { Cantidad de } \\
\text { Elementos/ Number } \\
\text { of Elements }\end{array}$ & $\begin{array}{c}\text { Cantidad de } \\
\text { Nodos / Number of } \\
\text { Nodes }\end{array}$ & $\begin{array}{c}\text { Tiempo aproximado* } \\
\text { (h:m)/ Approximate } \\
\text { time }^{*}(\mathrm{~h}: \mathrm{m})\end{array}$ \\
\hline \multirow{2}{*}{ MEF (a) } & Perno/ Stud & 156 & 180 & \multirow{2}{*}{$0: 15$} \\
\hline & Losa/ Salab & 1963 & 581 & \\
\hline \multirow{2}{*}{ MEF (b) } & Perno/ Stud & 204 & 232 & \multirow{2}{*}{$1: 20$} \\
\hline & Losa/ Salab & 4316 & 1068 & \\
\hline \multirow{2}{*}{ MEF (c) } & Perno/ Stud & 408 & 359 & \multirow{2}{*}{$1: 40$} \\
\hline & Losa/ Salab & 4704 & 1172 & \\
\hline \multirow{2}{*}{ MEF (d) } & Perno/ Stud & 964 & 805 & \multirow{2}{*}{$2: 23$} \\
\hline & Losa/ Salab & 5490 & 1343 & \\
\hline \multirow{2}{*}{ MEF (e) } & Perno/ Stud & 964 & 805 & \multirow{2}{*}{ 4:00 } \\
\hline & Losa/ Salab & 8501 & 2138 & \\
\hline
\end{tabular}

En la cantidad de elementos y nodos de la losa están contenidos los del anillo perimetral.

*Se ha usado un procesador Pentium 4 a $2.8 \mathrm{GHz}$.

The number of elements and nodes in the slab includes those in the perimetral ring.

*A Pentium $4 @ 2.8 \mathrm{GHz}$ processor was used 


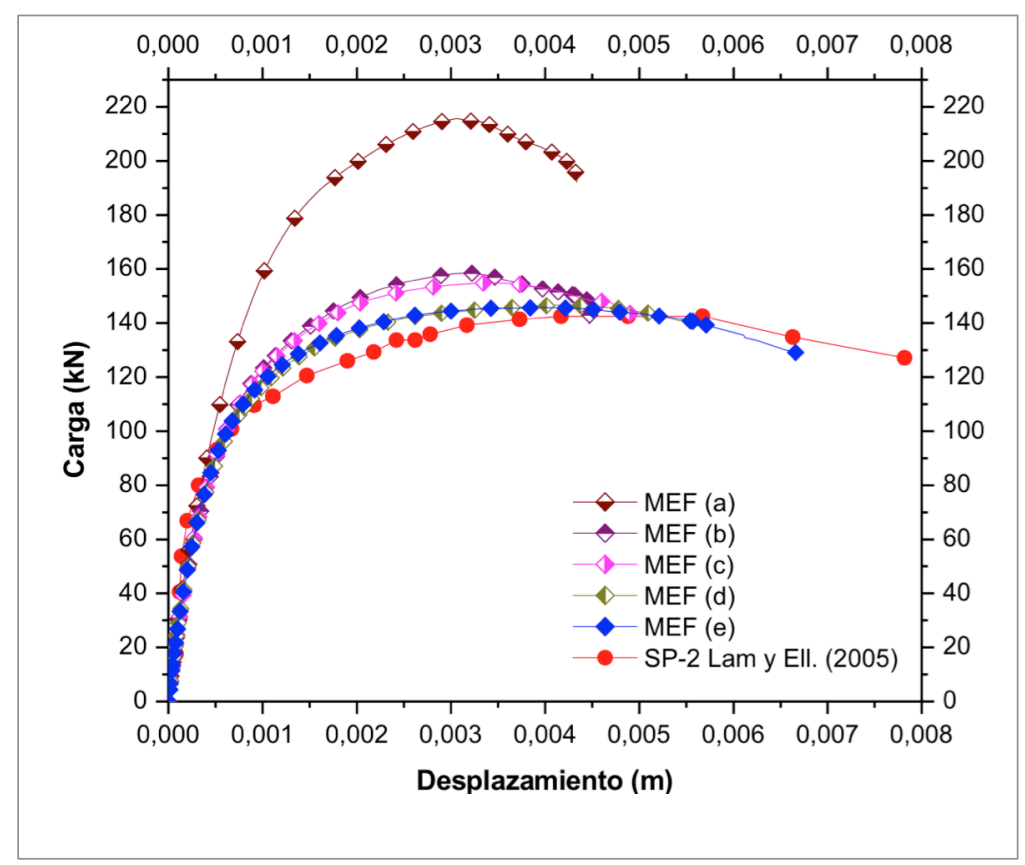

Figura 4. Curvas de comportamiento Carga vs Desplazamiento de la probeta Figure 4. Behaviour curves Load vs. Displacement of the specimen

Figure 4 shows the load vs. vertical displacement curves of the test, according to the configurations previously outlined and the test's experimental curve.

No significant difference is observed between the curves of models FEM (d) and FEM (e), and they are both very close to the physical experiment. 


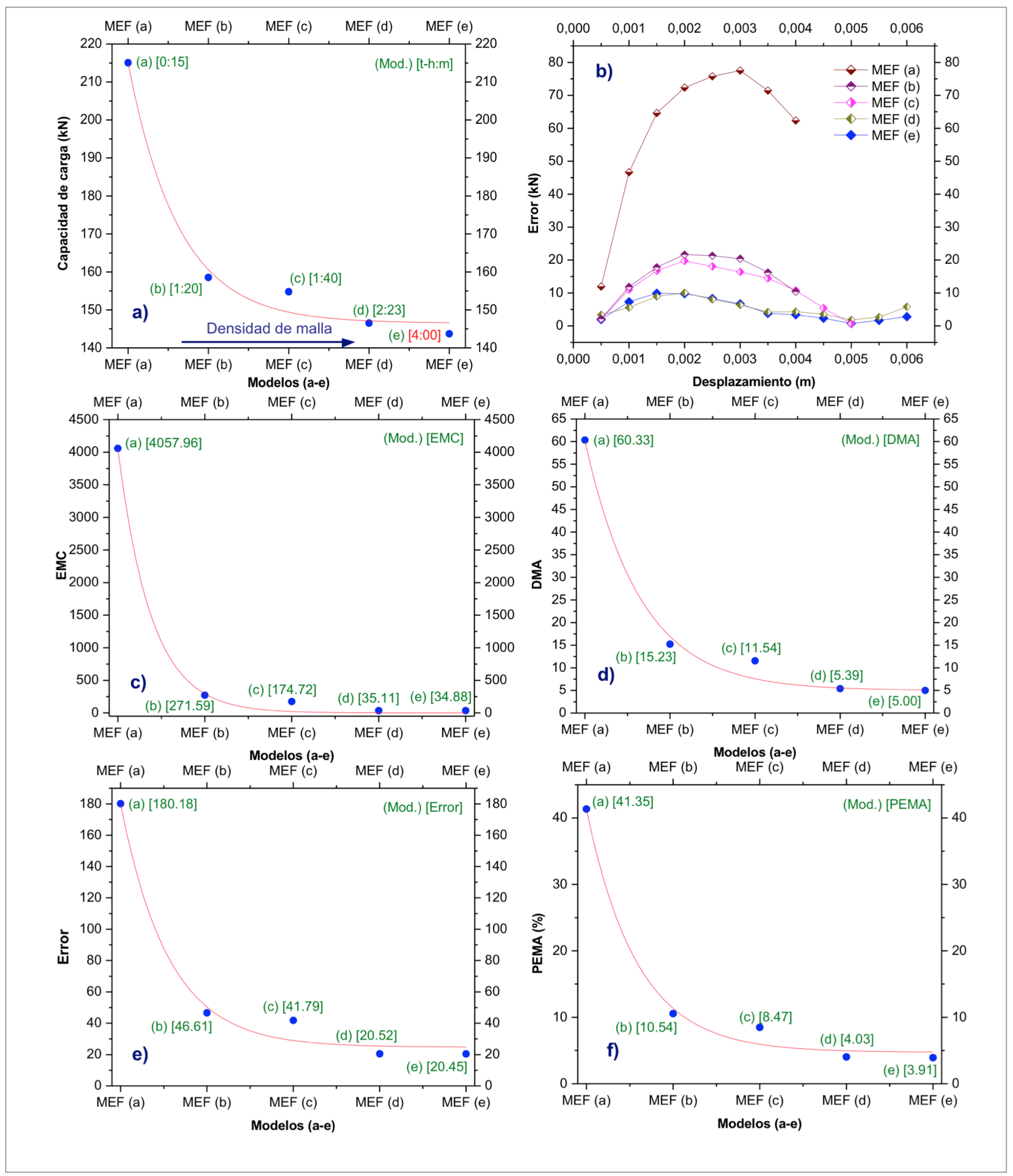

Figura 5. a) Comportamiento de la densidad de malla, b) Error absoluto, c) Error medio cuadrático, d) Desviación absoluta media, e) Error según norma del espacio euclidiano, f) Porcentaje del error medio absoluto

Figure 5. a) Behaviour of mesh density, b) Absolute error c) Mean squared error, d) Absolute mean deviation,

e) Error according to Euclidean space norm, f) Percentage of mean absolute error 
Forecasting errors for each of the theoretical models have been studied, as well as other measurements of dispersion. Figure 5 graphically shows the behaviour of the results that obtain each one of these measurements of error and deviation.

The estimated error expressions are indicated below:

- Absolute error according to norm:

$$
e_{i}=\left|Q_{e(i)}-Q_{n(i)}\right|
$$

Where: $Q_{e(i)}$ is the $i$-th load of the experimental test,

$Q_{n(i)}$ the $i$-th load obtained in the model

- $\quad$ According to Eculidean space norm:

$$
e=\sqrt{\sum_{i=1}^{n}\left(Q_{e(i)}-Q_{n(i)}\right)^{2}}
$$

Other measurements of error and dispersion were determined, and are shown in Table 3.

Tabla 3. Medidas de error

Table 3. Measurements of error

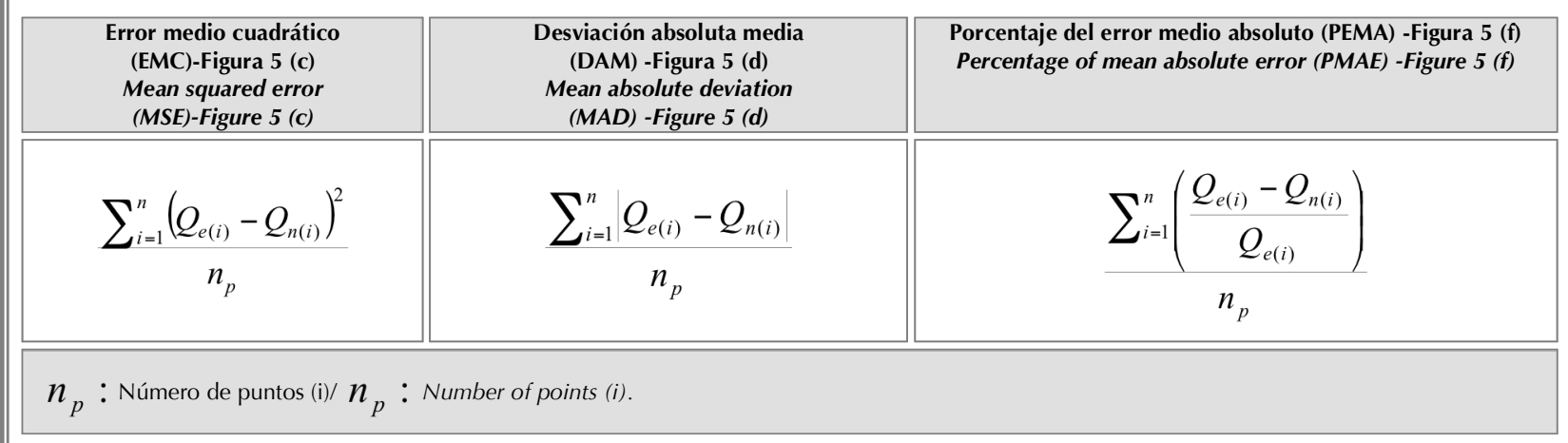

Observing Figures 4 and 5 (a) one can appreciate that as the mesh is refined, the differences obtained in terms of behaviour curves (between the numerical model and the physical test) and the relation with load capacities are smaller.

Analysing the measurements of error shown in Figure 5, it can be concluded that the FEM (d) and (e) mesh densities offer the most accurate values. Although FEM (e) presents a larger computational cost, it has lower error, which can be validated in Figure 5 (c) with the mean squared error and the rest of the analysed measurements. Finally, the mesh density of the FEM (e) model is adopted despite its higher computational requirements. 


\section{Validation of the modelling process}

\section{a) Simplification by Symmetry}

Thus far, the whole modelling process has been approached through the virtual simulation of Model I, with a maximum computer effort of four hours using the optimal mesh density. This model is symmetric from the standpoint of physical mechanics and loading, which allows for the proposal of Model II as shown in Figure 2. The validity of the aforementioned simplification by symmetry has been proven in previous research by the author (Bonilla, 2008), and alsoin Lam and Ellobody (2005), and is thus not further discussed in the current paper.

\section{b) Reinforcement of the Concrete Slab}

In models I and II, the presence of reinforcement steel is unaccounted for. This decision has been made considering the negligible influence of the reinforcement on the bearing capacity of the connection, which can be verified in the work of Lam and Ellobody (2005), and of the current paper's author (Bonilla, 2008).

\section{c) Stud-Concrete Contact Surface}

The stud-concrete surface has been treated as rigid instead of as a normal-tangential frictional contact, so as to avoid numerical convergence issues. The nodes located on the connector's surface have been merged with the concrete's surface, disconnecting those located in the stud's semicylindrical area, opposite to the direction of load application (Figure 7(a)). The disconnection of the said nodes is based on research by Jayas and Hosain (1987), and Kitoh and Sonoda (1990), which confirms that under low load levels there existsloss of contact at the stud's back end. This statement is numerically verified. Figures 6 (a) and (b) show two cuttingplanes for the virtual model of specimen SP-2 - for approximately $66 \%$ and $100 \%$ of its load capacity respectively - where the detachment of the stud's back end can be clearly observed over a length Ls, which increases as the load grows. Attention must be paid to the detachment between the profile and the concrete slab in the area (d).

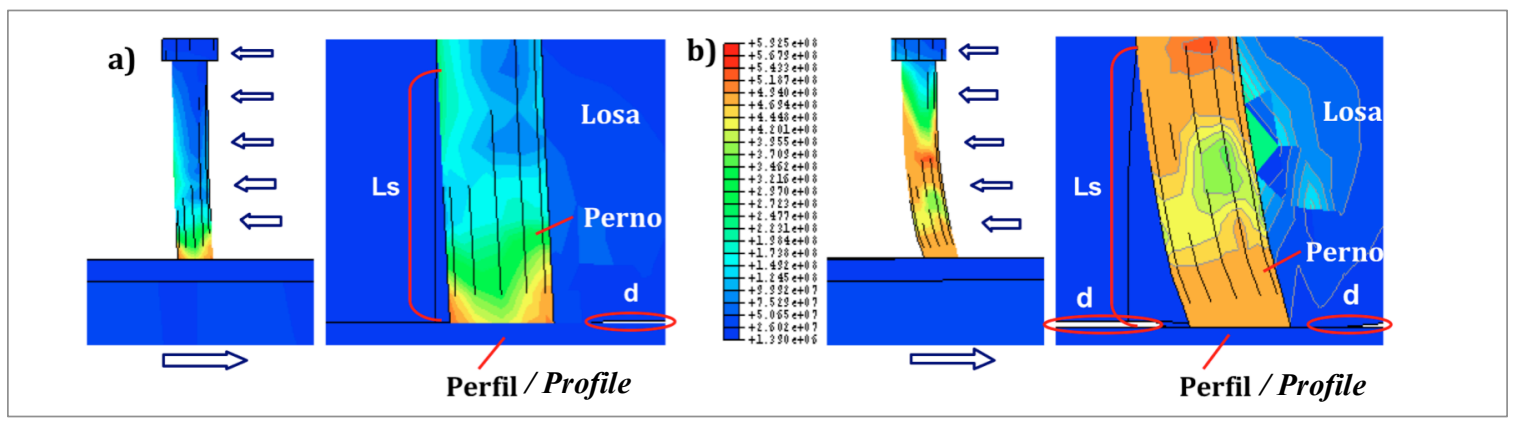

Figura 6. Estado tenso-deformacional del perno. a) $94 \mathrm{kN}$, b) $143 \mathrm{kN}$

Figure 6. Tense-deformational state of the stud. a) $94 \mathrm{kN}$, b) $143 \mathrm{kN}$ 
a)

Contacto perno-hormigón

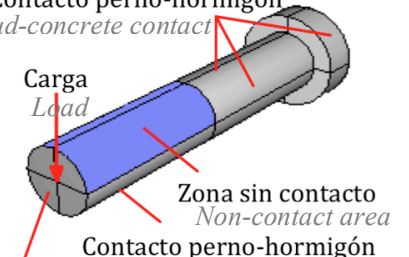

Contacto Stud-concrete contact perno-perfil I

Stud-profile contact 1

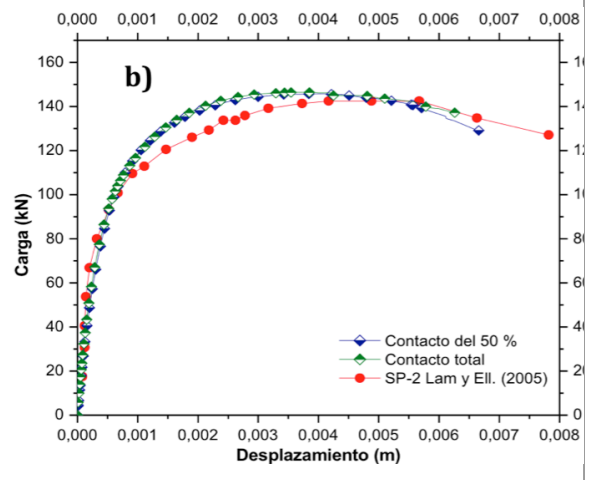

Figura 7. a) Condiciones de frontera del conector, b) Curvas de comportamiento para diferentes áreas de contacto

Figure 7. a) Connector boundary conditions, b) Behaviour curves for different areas of contact

The optimal non-contact distance at which nodes should be disconnected is approximately $50 \%$ of the beam's length, as studied by Bonilla et al. (2007). This is of the upmost importance when Lam and Ellobody's (2005) bilinear model is used for concrete. Conversely, if the Concrete Damage Plasticity Model is used, the connection's behaviour is practically unaffected when $50 \%$ of the beam's length - of its upper semi-cylindrical part, specifically - is freed or the nodes of the whole surface surrounding the connector remain united (Bonilla et al., 2007). Figure 7 (b) shows the behaviour curves for both cases, where it can be observed that the theoretical models coincide in nearly the complete domain of response. This allows for the connection of every node in the stud-concrete interface using the Concrete Damage Plasticity Model.

\section{d) Simulation of different connectors tests}

Figure 8 shows examples of the good correspondence between the simulation of connector tests from the proposed model, and the results obtained from the experiments by Lam and Ellobody (2005). In every case, all physical-mechanical properties of the specimen in Figure 1 are maintained, with the exception of the cubic compressive strength of concrete, which shows values of 20,30 and 35 MPa respectively.
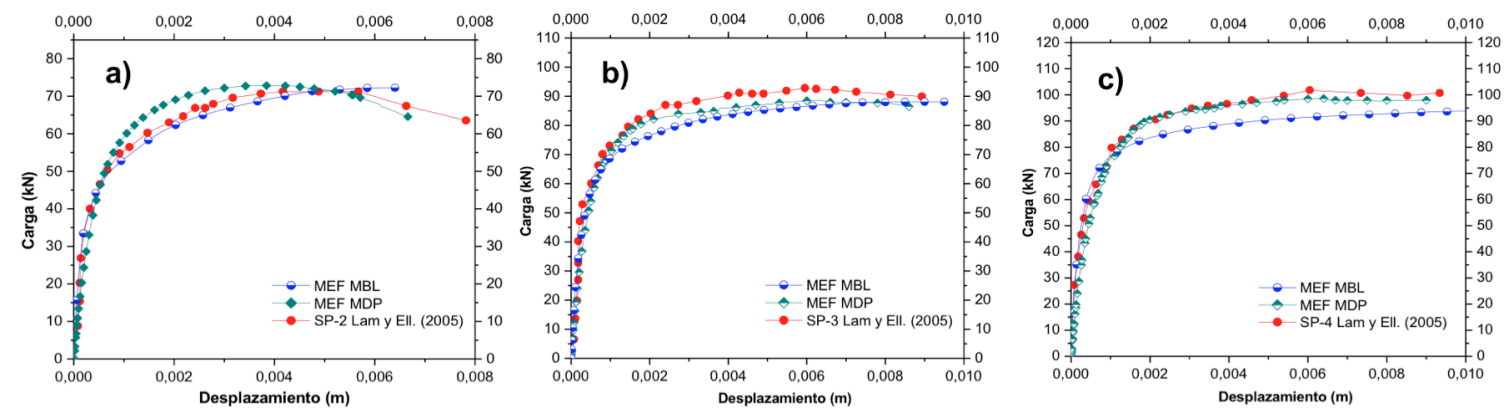

Figura 8. Curvas de comportamiento carga vs desplazamiento: a) $\left.\left.\mathrm{f}_{\mathrm{c}}{ }_{\mathrm{c}}=20 \mathrm{MPa}, \mathrm{b}\right) \mathrm{f}^{\prime}{ }_{\mathrm{c}}=30 \mathrm{MPa}, \mathrm{c}\right) \mathrm{f}_{\mathrm{c}}{ }_{\mathrm{c}}=35 \mathrm{MPa}$

Figure 8. Load vs displacement curves: a) $f_{c}^{\prime}=20 \mathrm{MPa}$, b) $\left.f_{c}^{\prime}=30 \mathrm{MPa}, c\right) f_{c}^{\prime}=35 \mathrm{MPa}$ 


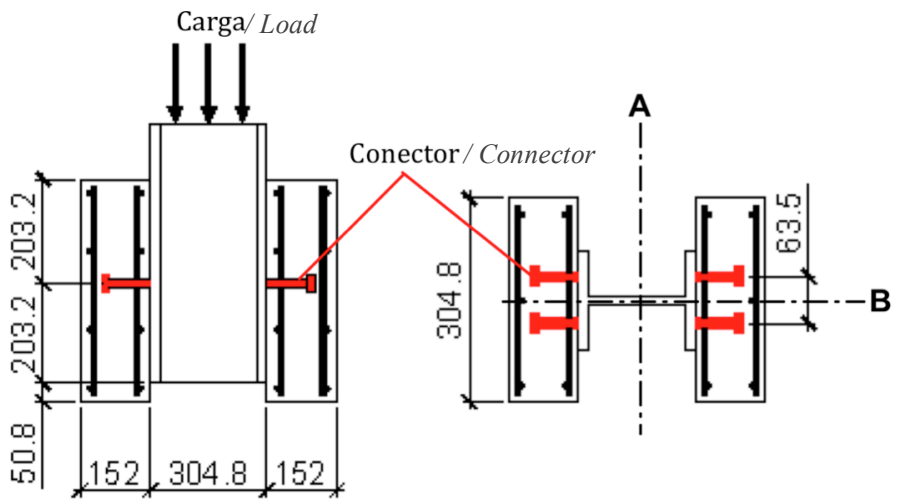

Figura 9. Curvas de comportamiento carga vs desplazamiento: a) $\left.\left.\mathrm{f}_{\mathrm{c}}^{\prime}=20 \mathrm{MPa}, \mathrm{b}\right) \mathrm{f}_{\mathrm{c}}{ }_{\mathrm{c}}=30 \mathrm{MPa}, \mathrm{c}\right) \mathrm{f}_{\mathrm{c}}{ }_{\mathrm{c}}=35 \mathrm{MPa}$

Figure 9. Schematic of the specimen used by Chapman and Balakrishnan (1964)

With the aim of validating the model using a specimen other than Lam and Ellobody's (2005), the specimen from series PB-1 of the work by Champan and Balakrishnan (1964) has been selected. It is composed of a profile of 12 in $x 6$ in $x$ 44 lib (B.S.B), with concrete slabs of $305 \times 457 \times 152 \mathrm{~mm}$ (length $x$ width $x$ thickness) and compressive strength of 34.48 MPa on each side, attached to the wings with two stud connectors of $19.05 \times 100 \mathrm{~mm}$, ultimate tensile stress of $522 \mathrm{Mpa}$, and modulus of deformation of $210000 \mathrm{MPa}$ (Figure 9).

Figure 8 and Table 4 show the results derived from virtual simulation considering both the Concrete Damage Plasticity (FEM DPM) and bilinear (FEM BLM) models for concrete.

Tabla 4. Resultados experimentales y de la simulación virtual

Table 4. Experimental and virtual simulation results

\begin{tabular}{|c|c|c|c|c|c|c|}
\hline Espécimen/Specimen & $\begin{array}{c}\mathbf{f}^{\prime}{ }_{c} \\
(\mathrm{MPa})\end{array}$ & $\begin{array}{c}Q_{\text {scexp }} \\
(k N)\end{array}$ & $\begin{array}{c}\mathbf{Q}_{\text {sc-MEF }} \\
\text { MBL } \\
(\mathrm{kN})\end{array}$ & $\begin{array}{c}\mathbf{Q}_{\text {sc-MEF }} \\
\text { MDP } \\
(\mathbf{k N}) \\
\end{array}$ & $\begin{array}{c}\text { Dif. MBL/ Dif. BLM } \\
(\%)\end{array}$ & $\begin{array}{c}\text { Dif. MDP/ Dif. DPM } \\
(\%)\end{array}$ \\
\hline SP-2 Lam y Ell. (2005) & 20.00 & 71.60 & 72.25 & 71.85 & 0.91 & 0.35 \\
\hline SP-3 Lam y Ell. (2005) & 30.00 & 93.00 & 88.10 & 88.58 & 5.27 & 4.75 \\
\hline SP-4 Lam y Ell. (2005) & 35.00 & 102.00 & 94.40 & 98.50 & 7.45 & 3.43 \\
\hline PB-1 Ch. y B. (1964) & 34.48 & 103.00 & 98.36 & 99.28 & 4.50 & 3.61 \\
\hline \multicolumn{7}{|c|}{ 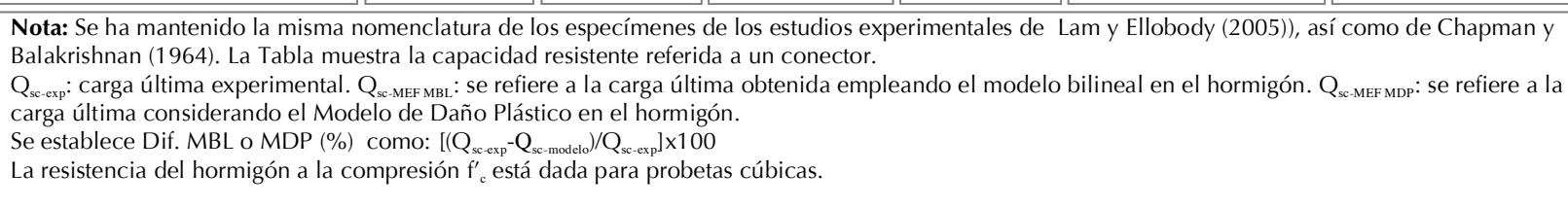 } \\
\hline
\end{tabular}


It should be clarified that in presenting the calibration and validation processes above, the behaviour curves for Lam and Ellobody's (2005) SP-2 specimen have been completely represented, considering load referred to both its connectors. In Figure 8 and Table 4, behaviour and load capacity are referred to an individual connector.

The differences in maximum load capacity between the models and experiments are less than 5\% when using the Concrete Damage Plasticity Model. On the other hand, when using the bilinear model the differences are larger for two specimens (SP-3, SP-4), but still below 10\%. These results allow for the validation of the initial hypothesis, as well as of the whole modelling process.

\section{Estimation of ullimate bearing capacity of the connection}

The calculation of the ultimate bearing capacity of stud connectors is considered in the AISC-LRFD (2005), EC-4 (2004) and NR 080-2004 norms. In AISC-LRFD, the bearing capacity of the connection $\left(Q_{s c}\right)$ is estimated from the following Equation (1):

$$
\boldsymbol{Q}_{s c}=0.5 \cdot \boldsymbol{A}_{s c} \cdot \sqrt{\boldsymbol{f}_{c}^{\prime} \cdot \boldsymbol{E}_{c}} \leq \boldsymbol{R}_{g} \cdot \boldsymbol{R}_{p} \cdot \boldsymbol{A}_{s c} \cdot \boldsymbol{F}_{u}
$$

Equation (1) adopts form (2) for connectors in beamsolid slabsections:

$$
\boldsymbol{Q}_{s c}=0.5 \cdot \boldsymbol{A}_{s c} \cdot \sqrt{\boldsymbol{f}^{\prime}{ }_{c} \cdot \boldsymbol{E}_{c}} \leq \boldsymbol{A}_{s c} \cdot \boldsymbol{F}_{u}
$$

Where, $f^{\prime}{ }_{c}$ is the cylindrical compressive strength ofconcrete (Mpa), $F_{u}$ is the minimum specified ultimate tensile stress ofsteel for the connector $(\mathrm{MPa}), A_{s c}$ is the connector's cross section area $\left(\mathrm{m}^{2}\right)$ and $E_{c}$ is the modulus of deformation of concrete (MPa). $R_{p}$ and $R_{g}$ are reduction factors.

EC-4 presents a similar approximation, expressed in (3):

$$
\boldsymbol{Q}_{s c}=0.37 \cdot \alpha \cdot \boldsymbol{A}_{s c} \cdot \sqrt{\boldsymbol{f}_{c k} \cdot \boldsymbol{E}_{c}} \leq 0.8 \cdot \boldsymbol{A}_{s c} \cdot \boldsymbol{f}_{u}
$$

Where $\boldsymbol{\alpha}$ is expressed as (4):

$$
\alpha=0.2 \cdot\left(\frac{h_{c}}{d}+1\right) \quad \text { para } 3 \leq \frac{h_{c}}{d} \leq 4 \quad y \quad \alpha=1 \quad \text { para } \frac{h_{c}}{d}>4
$$

Where, $h_{c}$ is the height of the connector $(\mathrm{mm}), d$ is the diameter of the connector $(\mathrm{mm}), f_{c k}$ is the cylindrical compressive strength of concrete (MPa) and $f_{u}$ is the ultimate bearing capacity of steel for the connector (MPa). 
The NC 080-2004 dictates the same expression (2) established in the AISC and as a result will not be addressed again.

A study to evaluate the accuracy of the expressions established in the analysed norms has been carried out considering a wide range of connectors with commercial diameters $[12.7 \mathrm{~mm}(1 / 2 \mathrm{in}), 15.88 \mathrm{~mm}(5 / 8 \mathrm{in}), 19.05 \mathrm{~mm}(3 / 4$ in), $22.22 \mathrm{~mm} \mathrm{(T/8}$ in) y $25.40 \mathrm{~mm}$ (1 in)]. Figure 10 is a graphic representation where a comparison is established between the results of the numeric models previously calibrated and the values of the ultimate bearing capacity of the connectors estimated according to the analysed norms for different strengths of concrete. It can be observed that the expression that EC-4 (2004) establishes predicts a close approximation of the bearing capacity of the connectors, for diameters between 12.70 and $19.05 \mathrm{~mm}$. For diameters of 22.22 and $25.40 \mathrm{~mm}$, the said norm overestimates, in the majority of the cases, the ultimate bearing capacity of the connectors, sometimes with values of over $15 \%$. Moreover, the AISC-LRFD (2005) and NR 080-2004 overestimate the ultimate bearing capacity of the connectors for all of the analysed diameters. In some cases, for 22.22 and $25.40 \mathrm{~mm}$ connectors, these differences are in the order of $50 \%$. (See Figure $10 \mathrm{~d}$-e).

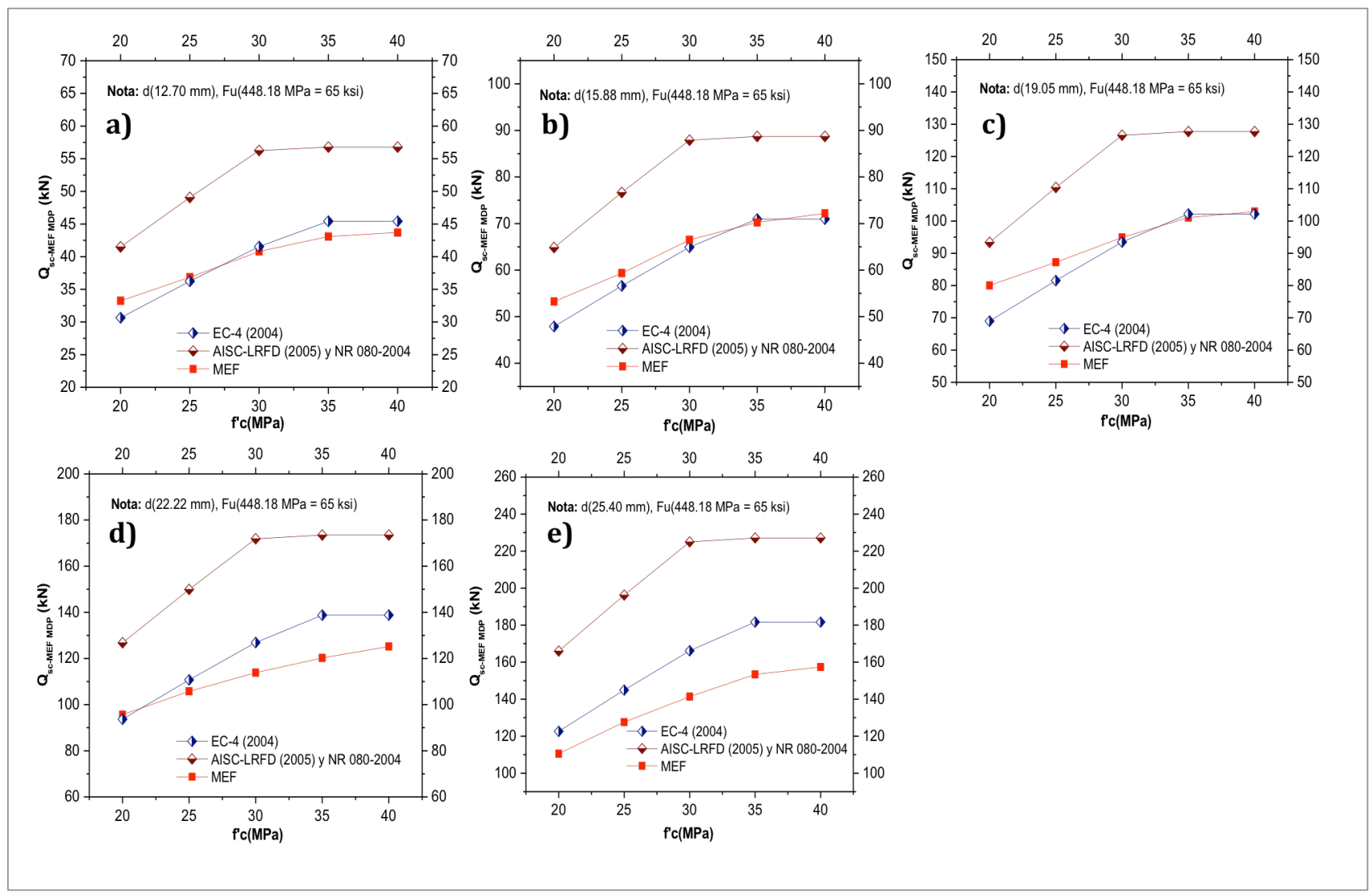

Figura 10. Estudio comparativo para diámetros de: a) $12.70 \mathrm{~mm}$, b) $15.88 \mathrm{~mm}$, c) $19.05 \mathrm{~mm}$, d) $22.22 \mathrm{~mm}$, e) $25.40 \mathrm{~mm}$

Figure 10. Comparative study for diameters of: a) $12.70 \mathrm{~mm}$, b) $15.88 \mathrm{~mm}$, c) $19.05 \mathrm{~mm}$, d) $22.22 \mathrm{~mm}$, e) $25.40 \mathrm{~mm}$ 
It is necessary to comment that the virtual modelling of the specimens, with the aim of evaluating the precision of current expressions in the studied norms, has been done considering the Plastic Damage Model for concrete.

\section{Conclusions}

- It has been found that the consideration of a rigid joint at the stud-concrete interface, in correspondence with the consulted literature, is an appropriate approach to the phenomenon of normal and tangential frictional contact which avoids numerical convergence issues.

- From the behaviour curves obtained as a result of the numerical models, it can be concluded that the simulation of the test is adequate, as there proves to be a good correspondence between the experimental and numerical results. Differences in bearing capacity below $5 \%$ are obtained when the Plastic Damage Model for concrete is used. This allows for the use of the FEM to be validated to study the behaviour of connectors and moreover it demonstrates the efficiency of this novel constitutive model based in damage mechanics.

- It has been proved that EC-4 (2004) adequately predicts the bearing capacity of the connection for diameters below or equal to $19.05 \mathrm{~mm}$. The same cannot be said for diameters of 22.22 and $25.4 \mathrm{~mm}$, where non-conservative results are obtained. Conversely, the norms AISC-LRFD (2005) and NR 080-2004 overestimate the bearing capacity of the connection for all diameters in the commercial range studied.

\section{Acknowledgements}

The authors of this paper wish to thank CAPES - Brazil for their support in funding this research.

\section{Referencias/References}

ABAQUS. (2003), User's Manual, Ver. 6.4-1, Hibbitt, Karlson and Sorensen, Inc.

Bonilla J. (2008), Estudio del comportamiento de conectadores tipo perno de estructuras compuestas de hormigón y acero mediante modelación numérica. Tesis Doctoral. Universidad Central de Las Villas. Sta. Clara, Cuba. 201 p.

Bonilla J., Larrúa R., Mirambell E., Recarey C. (2007), Estudio de la influencia de la resistencia del hormigón en el comportamiento de conectadores mediante simulación numérica y análisis experimental. , Revista Ingeniería Civil, No 147, Madrid, España, p 57-64.

Chapman J. C. y Balakrishnan S. (1964), Experiments on Composite Beams. Journal of Structural Engineer, Vol 42, No 11, p 369-383.

Ellobody E., Young B. (2006), Performance of shear connection in composite beams with profiled steel sheeting, Journal of Constructional Steel Research, No 62, p 682-694.

Eurocode 4 (EN 1994-1-1), Desing of Composite Steel and Concrete Structures - Part 1.1(2004), European Committee for Standardization, Brussels.

Hernández H., Bonilla J. Rodríguez G. (2014), Estudio del comportamiento de vigas compuestas de hormigón y acero mediante simulación numérica. Revista Ingeniería de Construcción, Vol 29, No 1, Santiago, Chile, p 5-21.

Jayas B. S. y Hosain M. U. (1988), Behavior of Headed Studs in Composite Beams: Push-out Test. Canadian Journal of Civil Engineering, Vol 15, No 2, p 240-253. 
Kitoh H. y Sonoda K. (1990), Forces on the Studs in a Steel Plate and Concrete Slab. International Association for Bridge and Structural Engineering (LABSE) Symposium, Brussels, p 185-190.

Lam D. y Ellobody E. (2005), Behavior of Headed Stud Shear Connectors in Composite Beam, Journal of Structural Engineering, Vol 131, No 1, p 96-106.

Lee J. y Fenves G. L. (1998), Plactic-Damage Model for Cyclic Loading of Concrete Structures, Journal of Engineering Mechanics, Vol 124, No 8, p 892-900.

Load and Resistance Factor Design (LRFD) Specification for Structural Steel Building (2005), American Institute of Steel Construction (AISC), Inc., Chicago, IL.

Lubliner J., Oliver J., Oller S. y Oñate E. (1989), A Plastic-Damage Model for Concrete, International Journal of Solids and Structures, Vol 25, No 3, p 229-326.

Nie J. y Cai C. S. (2004), Steel-Concrete Composite Beams Considering Shear Slip Effects. Journal of Structural Engineering, Vol 129, No 4, p 495-506.

NR 080-2004, Cálculo de entrepisos compuestos de hormigón y acero con vigas de alma llena sometidos a carga estática. Código de buenas prácticas (2004), Norma ramal del Ministerio de la Construcción de Cuba.

Rambo-Roddenberry M. D. (2002), Behavior and Strength of Welded Stud Shear Connectors. PhD. Thesis University of Blacksburg, Virginia, EE.UU, $245 \mathrm{p}$.

Zienkiewicz O. C. y Taylor R. L. (2004), El Método de los Elementos Finitos, Quinta edición, Ed. CIMNE, Barcelona, España, Vol I, II, III. 